Women's Equality Union, Workers' Mutual Aid Society and three All-Russian women's congresses. It shows participation of various segments of the population in the women's movement. The author analyzes government policy on the women's issue and concludes about the results and significance of the women's movement.

Keywords: Russia, women's issue, women's movement, women's organizations, women's congresses

УДК 27-725(438)+94(571/5)(=162/1)"19"

СЕМЕНОВ Евгений Владимирович - кандидат исторических наук, доцент Восточно-Сибирского государственного института культуры (670031, Россия, Республика Бурятия, г. Улан-Удэ, ул. Терешковой, 1; sew11@таil.ru)

\title{
КАТОЛИЧЕСКИЕ СВЯЩЕННИКИ - УЧАСТНИКИ ВОССТАНИЯ 1863-1864 гг. В ССЫЛКЕ НА ТЕРРИТОРИИ ЗАБАЙКАЛЬЯ ВО ВТОРОЙ ПОЛОВИНЕ 1860-х гг.
}

\begin{abstract}
Аннотация. Польское восстание 1863-1864 гг. было не только самым крупным восстанием поляков в XIX в., но и разнородным по своему национальному и социальному составу. В рамках настоящей статьи автор рассматривает ссылку в Сибирь на каторжные работы католических священников, принимавших участие в восстании; условия отбывания ими каторжных работ и поселения на территории Забайкалья в 1864-1868 гг. Работа опирается на широкий круг источников, включающих архивные документы региональных архивов и воспоминания польских ссыльных второй половины ХIX в. Данная тема на сегодня является одним из наименее изученных аспектов польской ссылки середины и второй половины XIX в. Ключевые слова: польское восстание 1863-1864 гг., католические священники, польская ссылка, Забайкалье
\end{abstract}

$\Pi$ ольское восстание 1863-1864 гг, поднятое с целью восстановления независимости Польского государства, разделенного между Австрией, Пруссией и Россией в конце XVIII в., продолжалось около двух лет и было подавлено правительственными войсками. Отличительной особенностью данного восстания явилось массовое участие представителей самых разных социальных и политических групп польского общества. Немногочисленной, но заметной частью участников восстания были представители римско-католического духовенства, активно включившегося в повстанческую деятельность.

Изучением вопроса участия католических священников и монахов в польском восстании занимаются польские исследователи, и в настоящее время данная проблема детально разработана. Тем не менее продолжает оставаться открытым вопрос о пребывании ссыльных представителей католического духовенства на каторжных работах и поселении в Сибири. Исключение составляет поселение католических священников в д. Тунка, достаточно подробно рассмотренное в работах польских авторов.

Целью статьи является изучение периода нахождения католических священников на каторжных работах в Забайкалье. Научная новизна представленной темы заключается во введении в научный оборот ранее неизвестных материалов, отражающих положение католических священников в период отбывания ими каторжных работ на территории Забайкалья. 
Методологической основой данной статьи выступили работы польских и российских исследователей, рассматривающих вопросы участия католических священников в процессе подготовки восстания и непосредственного участия в боевых операциях против правительственных войск, в т.ч. основополагающие труды С. Кеневича, Е. Небэльского и др.

Католическое духовенство сыграло одну из важнейших идеологических ролей в подготовке польского восстания 1863-1864 гг. и его развитии. Объясняется данный факт тем, что в польском обществе XIX в. католическая религия занимала важное место и во многом способствовала его консолидации в условиях разделов и фактического отсутствия политических форм государственного функционирования [Kieniewicz 1983: 492-493]. Широкие возможности католического духовенства по воздействию на свою паству использовались и руководителями восстания [Бендин 2018]. Основными формами участия католических священников в восстании были зачитывание прокламаций Временного национального правительства в католических храмах; создание конспиративной сети и поставка повстанцам продовольствия, обмундирования и оружия; приведение к присяге повстанцев и участие в панихидах по убитым повстанцам и др.

Некоторые священники возглавляли отряды повстанцев и лично принимали участие в боевых действиях против правительственных войск. Самым известным католическим священником, возглавлявшим отряд повстанцев, был Станислав Бжуска. Его отряд был разбит правительственными войсками одним из последних.

Вовлечение патриотически настроенного духовенства в активные действия в процессе восстания, в т.ч. и с оружием в руках, привело к ужесточению правительственной политики в отношении католической церкви в Российской империи.

Вопрос количественного состава католических священников, принимавших участие в восстании и приговоренных к ссылке на каторжные работы и на поселение в Сибирь, до настоящего времени остается открытым. Польские исследователи оперируют цифрами от 300 до 500 чел. [Niebelski 2011: 33]. По подсчетам А.К. Тихонова, основанным на документах Российского государственного исторического архива (РГИА), за прямое или косвенное участие в польском восстании 1863-1864 гг. были приговорены к каторжным работам в Сибири 183 священника [Тихонов 2004: 142].

В отличие от Западной Сибири, куда католические священники ссылались в основном на жительство, в Восточную Сибирь, и в первую очередь, в Забайкалье, священники направлялись для отбывания каторжных работ [Никулина 2011: 155-156]. По нашим подсчетам, на территории Забайкалья в 1864-1868 гг. на каторжных работах находились 87 представителей католического духовенства. На начальном этапе отбывания каторжных работ в Забайкалье католические священники находились в общем числе ссыльных участников восстания. Впоследствии местная администрация принимает решение нейтрализовать влияние священников на ссыльных и размещает их в Акатуевском руднике как одном из наиболее изолированных мест каторги. По мере окончания срока каторжных работ и перехода на поселение католические священники переводились в д. Тунка, ставшую местом поселения представителей духовенства по распоряжению генерал-губернатора Восточной Сибири в 1866 г.

К числу основных рудников и горных заводов, предназначенных для размещения ссыльных участников польского восстания 1863-1864 гг, на территории Забайкалья относились Петровский железоделательный 
завод, Александровский сереброплавильный завод, Муравьевская гавань, Сивяковское тюремное помещение.

Первые группы польских ссыльных, в числе которых находились и католические священники, прибывают в Забайкалье уже в начале 1864 г. Основным местом размещения ссыльных на этом этапе становится Петровский железоделательный завод, однако в связи с быстрым заполнением казарменных помещений при заводе и прибытием новых партий ссыльных поляков перед областной администрацией встал вопрос перераспределения их по другим горным заводам.

Большая часть польских ссыльных была отправлена для размешения в Сивяковское тюремное помещение, созданное при верфи по строительству барж и лодок для нужд амурских сплавов. Местная администрация планировала разместить здесь до 800 ссыльных поляков. Максимальное число ссыльных во второй половине 1865 г. достигало 729 чел. Увеличение числа ссыльных привело к расширению территории тюремного помещения. На включенных площадях ссыльные получили разрешение заняться постройкой домов, число которых со временем возросло. Здесь же располагались казармы, хозяйственные помещения и постройки верфи по строительству барж.

Л. Зелонко, находившийся в рассматриваемый период в Сивяковском тюремном помещении, так описывает сформировавшееся поселение: «Городок наш мы назвали “маленькой Варшавой” и разделили его на две части: на Старый и Новый город, было там Краковское предместье, улицы Сенаторская, Королевская, Медовая, Депутатская и даже Железные ворота» [Zielonko Jastrzębiec 1906: 49].

В среде ссыльных складывались сложные и противоречивые отношения, обусловленные их разнообразным социальным состоянием, политическими взглядами, этнической и территориальной принадлежностью [Семенов 2019: 242]. Объединяющим началом для подавляющего большинства ссыльных являлась католическая религия. По вопросам проведения богослужения по католическому обряду следовало обращаться к католическому священнику в Чите. Однако находившийся в областной столице священник Андрей Юревич не мог часто посещать Сивяково в связи с тем, что он в рассматриваемый период занимался организационными вопросами переноса католического прихода из Нерчинского Завода в Читу. Находившиеся в числе ссыльных католические священники выступили инициаторами создания католической общины. Несмотря на то что они были лишены сана и им запрещалось проводить религиозные обряды, время от времени богослужения все же проводились. Воскресные и праздничные службы католические священники организовывали во всех местах размещения польских ссыльных. Свидетельства этого сохранились в воспоминаниях многих ссыльных поляков [Mężyński 1910: 89-90; Pamiętnik dra... 1930: 234; Zielonko Jastrzębiec 1906: 41-42].

Сложившаяся ситуация не осталась незамеченной местными властями. 24 января 1866 г. генерал-губернатор Восточной Сибири М.С. Корсаков в своем письме на имя военного губернатора Забайкальской области сообщал: «Дошло до сведения моего, что содержащиеся в местах заключения политические преступники устраивают самопроизвольно алтари под предлогом отправления Богослужения. Признавая устройство таковых алтарей вовсе неуместным и не имея в виду, чтобы закон разрешал подобные действия я покорнейше прошу Ваше Превосходительство отнюдь не допускать устройства подобных алтарей» 1 .

\footnotetext{
${ }^{1}$ Государственный архив Забайкальского края (ГАЗК). Ф. 1. Оп. 2 (п). Д. 52. Л. 50.
} 
По свидетельству Л. Зелонко, в Сивяковском тюремном помещении сложились два католических прихода, которые совпадали с границами так называемых Старого и Нового городов. Предполагаемый приход Старого города возглавлял Северин Гергелевич, а приход Нового города - Феликс Ковалевский. На протяжении 1865 г. число католических священников, оказавшихся в Сивяковском тюремном помещении, постоянно возрастало - от 3 в марте до 17 в конце октября 1 .

Л. Зелонко и П.Д. Баллод сообщают интересный факт о предпринятой ссыльными попытке построить здание молитвенного дома, в котором могли бы проводиться богослужения. Л. Зелонко также пишет о том, что негласное разрешение на строительство было получено от коменданта Заборовского. В июне 1866 г. началось строительство, было поставлено здание часовни, однако в момент проведения обряда освящения здание было оцеплено охраной и дан приказ прекратить богослужение [Zielonko Jastrzębiec 1906: 56-57]. Л. Зелонко утверждает, что здание католической часовни было переоборудовано под православную церковь, что не подтверждается архивными документами и не соответствует действительности. В свою очередь, П. Баллод пишет, что освящение часовни и первое богослужение в ней все же состоялось, но после его завершения были запрещены дальнейшие собрания, а данное здание было переоборудовано под казарменное помещение [Валескали 1987: 159].

Они оба подтверждают тот факт, что ссыльным удалось спрятать предметы богослужения и избежать их изъятия. Тем не менее случаи изъятия богослужебных предметов происходили ${ }^{2}$.

Отношение к католическим священникам в среде ссыльных было неоднозначным. Для большинства ссыльных поляков священники, несомненно, являлись связующим звеном с прежним жизненным укладом, польскими национальными и религиозными традициями. В ряде случаев священники освобождались от обязательных работ, по словам П.Д. Баллода, «под тем предлогом, что они оказали краю известную услугу» [Валескали 1987: 157].

Во второй половине 1866 г. большинство католических священников, не окончивших срок каторги, были переведены на каторжные работы в Акатуевский рудник ${ }^{3}$. По свидетельству П.Д. Баллода, также отправленного в Акатуевский рудник в 1866 г., там находились на каторжных работах около 70 католических священников [Валескали 1987: 159]. В 1867 г. к их числу добавились и те священники, которые находились в д. Дарасун. По нашим данным, в Акатуе в 1866-1868 гг. на каторжных работах находились 76 ксендзов из общего числа 83 польских ссыльных ${ }^{4}$.

Находившийся на каторжных работах в Александровском сереброплавильном заводе ссыльный священник Рох Климкевич 4 апреля 1867 г. публично отрекся от своего сана [Niebelski 2011: 317]. Об этом факте в своих воспоминаниях сообщал и П.Д. Баллод, с которым Р. Климкевич проживал в одной камере [Валескали 1987: 159].

В большинстве воспоминаний польских ссыльных католические священники характеризуются исключительно с положительной стороны. Исключение составляют воспоминания В. Черника, в которых он дает отрицательную характеристику некоторой части ссыльных священников: «Среди польских ссыльных в Восточной Сибири было около шестидесяти ксендзов, и к сожа-

1 ГАЗК. Ф. 1. Оп. 1 (п). Д. 147. Л. 14, 41.

2 ГАЗК. Ф. 1. ОП. 2 (п). Д. 52. Л. 97.

3 ГАЗК. Ф. 1. Оп. 2 (п). Д. 52. Л. 246(об).

4 ГАЗК. Ф. 1. ОП. 2 (п). Д. 52. Л. 246(об). 
лению, только третья часть их вела себя согласно своему священническому статусу, остальные были пятном на товарищеской жизни» [Czernik 1914: 51]. Согласны с этой точкой зрения и современные польские исследователи, занимающиеся изучением истории ссылки католических священников в Сибирь во второй половине XIX в. [Niebelski 2011: 33].

П.Д. Баллод, близко столкнувшийся с католическими священниками в Акатуевском руднике, также давал нелестную характеристику католическим священникам: «Когда мне пришлось поближе познакомиться с ксендзами, то я был сильно поражен крайне узким взглядом этого сословия на свою специальность; ксендзы могли говорить очень много и витиевато, вполне бессодержательно; то был простой набор слов, кое-как связанных. Вследствие такой их способности говорить много о чем попало и вследствие того подобострастия, какое им выказывал простой народ, дававший им средства и повод держаться с особенной важностью, они являлись перед толпой более важными, чем другие люди, несравненно более их развитые» [Валескали 1987: 160].

В ноябре 1865 г. вышло распоряжение генерал-губернатора Восточной Сибири о переводе всех ссыльных католических священников, находившихся на тот момент на каторге и поселении в Восточной Сибири, в д. Тунка. С этого времени практически все католические священники были направлены в этот небольшой населенный пункт, расположенный в Тункинской долине. Первые священники начинают прибывать сюда зимой и в начале весны 1866 г. По мере выхода на поселение ссыльных священников с длительными сроками они также направлялись на поселение в Тунку. Перевод ознаменовал собой начало нового этапа в истории ссылки католических священников в Сибири.

Рассматриваемый период пребывания католических священников на территории Забайкалья сыграл значимую роль для внутренней организации сообщества польских ссыльных в условиях пребывания на каторжных работах. Католические священники не только служили связующим звеном ссыльных с родиной и традициями польского народа, но также выступали против ассимиляционной политики правительства. В связи с этим центральные и местные власти рассматривали представителей католического духовенства как наиболее опасный элемент в среде ссыльных. Результатом этого явилась изоляция священников первоначально в Акатуевском руднике, а впоследствии - в д. Тунка.

Непродолжительное пребывание католических священников в Забайкалье требует своего дальнейшего изучения с привлечением широкого круга исторических источников, в первую очередь архивных документов региональных архивов.

\section{Список литературы}

Бендин А.Ю. 2018. Роль римско-католического духовенства СевероЗападного края Российской империи в польском восстании 1863 г. - Вестник Российского университета дружбы народов. Сер. История России. Т. 17. № 2. С. 357-387.

Валескали П.И. 1987. Революционный демократ Петр Давыдович Баллод: материалы к биографии. Рига: Зинатне. 301 с.

Никулина И.Н. 2011. Представители католического духовенства в западносибирской ссылке (60-70-е гг. XIX в.). - Известия Иркутского государственного университета. Сер. Политология. Религиоведение. № 1(6). С. 155-160.

Семенов Е.В. 2019. Взаимоотношения польских политических ссыльных в Забайкалье в 60-70-е гг. XIX в. - Сибирская ссылка: сборник научных статей (отв. ред. Л.М. Дамешек, А.А. Иванов, С.И. Кузнецов). Вып. 9(21). Иркутск: Оттиск. С. 240-257. 
Тихонов А. К. 2004. Власти и католическое население России в XVIII XIX веках. - Вопросы истории. № 3. С. 140-146.

Czernik W. 1914. Pamiętniki weterana. $1864 r$. Wilno: Druk Józefa Zawadzkiego w Wilnie. $87 \mathrm{~s}$.

Kieniewicz S. 1983. Powstanie Styczniowe. Warszawa: Państwowe Wydawnictwo Naukowe. $800 \mathrm{~s}$.

Mężyński L. 1910. Wspomnienia z powstania styczniowego i sybirskiej katorgi 1863 1869. Tarnopol. $162 \mathrm{~s}$.

Niebelski E. 2011. Tunka. Syberyjskie losy księży zesłańców 1863 roku. Wrocław: Polskie Towarzystwo Ludoznawcze. 394 s.

Pamiętnik dra Benedykta Dybowskiego od roku 1862 zaczawszy do roku 1878. 1930. Lwów : Wydawnictwo Zakładu Narodowego im. Ossolinskich. 627 s.

Zielonko Jastrzębiec L. 1906. Wspomnienia z Syberii od roku 1863-1869. Kraków: Spółka Wydawnicza Polska w Krakowie. 320 s.

\section{CATHOLIC PRIESTS - PARTICIPANTS OF THE 1863-1864 UPRISING IN EXILE IN THE TRANSBAIKALIA IN THE SECOND HALF OF THE 1860s}

\footnotetext{
Abstract. The Polish uprising of 1863-1864 was the largest uprising of Poles in the $19^{\text {th }}$ century. It was also characterized by ethnic and social heterogeneity of its participants. In this paper, the author examines the exile to Siberia of Catholic priests who took part in the uprising, as well as the conditions of hard labor and penal settlements in the Transbaikalia in 1864-1868. The work is based on a wide range of sources, including archive documents from regional archives and memoirs of Polish exiles of the second half of the $19^{\text {th }}$ century. This topic is one of the least studied aspects of the Polish exile in the middle and second half of the $19^{\text {th }}$ century.
}

Keywords: Polish uprising of 1863-1864, Catholic priests, Polish exile, Transbaikalia 